\title{
Recognizing Young Children's Expressive Styles of Emotions (2-6 Years Old)
}

\author{
Laila Qodariah, Lucia Voni Pebriani \\ Faculty of Psychology Universitas Padjadjaran, Bandung, Indonesia \\ Corresponding e-mail: laila.qodariah@unpad.ac.id
}

\begin{abstract}
One of the most important core features of emotional development is the ability to manage strong emotions and their expression in a constructive manner. Strengths in the area of emotional competence may help children cope effectively in particular circumstances. Meanwhile, emotional development often receives relatively less recognition as a core emerging capacity in the early childhood years, include in Indonesia. This study focused on expressive behavior of the primary and self-conscious emotion in early childhood life. The survey was conducted using guideline interview and analyzed by descriptive studies. Sample were 120 participants from Bandung, Jakarta, and Medan (60 samples of toddler and 60 samples of preschoolers). The result shows that both categories children mostly express their primary negative affect (i.e. sadness, anger) by crying or whining. For fear and disguise, most children avoiding the stimulus. This should be more concern for preschool children, because they should learn to express their feeling verbally to others and communicate with others can extends child's evaluation of and awareness of own feeling. There is a few contrast in expressive behavior of self-conscious emotion (i.e. shyness, and guilt) between these two children categories. Most of toddler express their negative emotion by avoiding the object or crying. While the preschooler can express their emotion using word (i.e. admitting their mistake or asking for an apology). The awareness of how they appear in the eyes of others is an important emotional resource to early socialization. The contrast ability to express the emotion between toddler and pre-school children are involve multiple emotion-related components that change over time as the child matures and in response to changing environmental interactions. That how the role of caregiver and teacher are important in develop the ability of children's regulation and their expression in a constructive manner.
\end{abstract}

Keywords: emotional development, expressive behavior of emotion, self-regulation

\section{INTRODUCTION}

Emotion is feeling, or affect, that occurs when people are in a state or an interaction that is important to them, especially one that influences their well-being. In many instances, emotions involve people's communication with the world (Santrock, 2011). One of the most important core features of emotional development is the ability to manage strong emotions and their expression in a constructive manner. Strengths in the area of emotional competence may help children cope effectively in particular circumstances (The National Scientific Council on the Developing, 2004). Emotional expressions serve the important functions of signaling to others how one feels. Emotional regulation plays a key role in children's ability to manage the demands and conflicts they face in interacting with others, while also promoting characteristics associated with positive developmental outcomes, including feelings of selfefficacy, pro-social behavior and supportive relationships with family and peers (Saarni, 2011). Moody and emotionally negative children are more likely to experience rejection by their peers, whereas emotionally positive children are more popular (Stocker \& Dunn, 1990; Santrock, 2011).

Emotional regulation typically increases as children mature. By the end of the preschool years, children who have acquired a strong emotional foundation have the capacity to anticipate, talk about, and use their awareness of their own and others' feelings to manage social interactions. As children acquire these emotional competence skills 
in a variety of contexts, they are more likely to effectively manage their emotions, become resilient in the face of stressful circumstances, and develop relationships that are more positive.

Cultural variations reveal the role of experience in emotion, for example in when, where, and how emotions should be express. For example, researchers have found that East Asian infant display less frequent and less intense positive and negative emotions than non-Latino White infants (Camras \& others, 1998; Santrock, 2011). Meanwhile, emotional development often receives relatively less recognition as a core emerging capacity in the early childhood years, included in Indonesia. As far as the exploration of current research at the Faculty of Psychology in Univesitas Padjadjaran, Universitas Indonesia, and Universitas Gajah Mada, the topic research of emotion regulation in children still small in number. Based on the survey conducted in the online library of the University of Indonesia, from 156 research topics related to emotions, there are only 16 research about children's emotion (10.26\%) and only $2.56 \%$ that focus on emotional problems in early childhood (Universitas Indonesia, 2016). In Universitas Gadjah Mada, there are 465 studies related to emotions, and only 43 research are focus on children's emotion (9.24\%) (Universitas Gadjah Mada, 2016). In Faculty of Psychology Universitas Padjadjaran only 49 research that focus on emotion and only 5 research are focus on children's emotion (Universitas Padjadjaran, 2016).

This study focused on expressive behavior of the primary and self-conscious emotion in early childhood life (2-6 years old) from three largest cities in Indonesia, which is Jakarta, Bandung, and Medan. Emotional expressions are those potentially observable surface changes in face, voice, body, and activity level (Lewis, 2008). However, if we can develop understanding of emotional development in early childhood life, this study will be able to support caregiver and teacher to evaluate and deal with children's emotion especially who present significant emotional or behavioral problems.

\section{METHODS}

Participant in this research were toddler $(n=60)$ and preschooler $(n=60)$ and their mothers carried out in Bandung, Jakarta, and Medan.

The survey conducted using interview guideline Emotional Development in Early Childhood developed by researcher, as you can see on this table 1 below. The surveyor was undergraduate student on Faculty of Psychology Universitas Padjadjaran.
The mother was interviewed using the guidelines interview and for completed the data, the children were observed during play session for about 15 minutes. Data was coded by qualitative analysis based on Emotional Regulation Pattern from Friedlmeier \& Trommsdorff (1999), and analyzed by descriptive studies.

Table 1. Interview Guideline "Emotional Development in Early Childhood"

\begin{tabular}{|c|c|c|}
\hline No & Dimension & Indicator \\
\hline \multirow[t]{5}{*}{1 . } & $\begin{array}{l}\text { Situation that } \\
\text { provoke the }\end{array}$ & $\begin{array}{l}\text { Situations / objects / events that } \\
\text { provoked children emotion }\end{array}$ \\
\hline & & Primary Emotion \\
\hline & & $\begin{array}{l}\text { Joy, Surprise, Interest, Fear, } \\
\text { Anger, Sadness, Disgust }\end{array}$ \\
\hline & & $\underline{\text { Self-conscious Emotion }}$ \\
\hline & & $\begin{array}{l}\text { Jealousy, Empathy, Shy, Guilt, } \\
\text { Pride, Embarrassment }\end{array}$ \\
\hline 2. & $\begin{array}{l}\text { Reaction } \\
\text { shown } \\
\text { children }\end{array}$ & $\begin{array}{l}\text { Reaction (physiological, verbal, } \\
\text { behavior, coping strategies) } \\
\text { when the child feels the emotion }\end{array}$ \\
\hline \multirow[t]{4}{*}{3.} & $\begin{array}{l}\text { Parental } \\
\text { Implication }\end{array}$ & $\begin{array}{l}\text { The way parents show the } \\
\text { emotion }\end{array}$ \\
\hline & & $\begin{array}{l}\text { The emergence frequency } \\
\text { emotion every day }\end{array}$ \\
\hline & & $\begin{array}{l}\text { The easiest emotion shown by } \\
\text { parents daily }\end{array}$ \\
\hline & & $\begin{array}{l}\text { The hardest emotion shown by } \\
\text { parents daily }\end{array}$ \\
\hline
\end{tabular}

Data was coded by these three step

(1) Write down the mother's answer about the children expression:

a. Primary Emotion: surprise, interest, joy, anger, sadness, fear, and disgust

b. Self-conscious emotions: jealousy, empathy, embarrassment, pride, shame, and guilt.

(2) The expression was coded into 6 different kind of emotional reaction, which are:

a. Facial Expression (i.e. smiling, laughing, numbing)

b. Gesture / Body Language (i.e. jumping, clapping, running)

c. Verbal Expression (i.e. crying, whining, saying something)

d. Activity (maintained the affect / reduce the affect) (i.e. keep playing, reaching, persuading) 
e. Support seeking (i.e. find mom, hugging mom, hugging toys/doll)

f. Physiological reaction (i.e. vomiting)

(3) The emotional reaction clustered into 3 different kind of Emotional Regulation Pattern based on Friedlmeier \& Trommsdorff about Model of Toddlers' Emotion Regulation (Friedlmeier \& Trommsdorff, 1999), which are:

a. Positive Emotion Regulation Children feeling of competence and selfefficacy, they have behavior reactions available that allow them to deal with such experiences by themselves without maternal support. In case of distress, the child uses the mother as a source of reference (or secure base)

b. Negative Emotion Regulation Children may have experienced not getting enough support to control their negative arousal, and they may not have developed strategies to regulate negative emotional experiences by themselves. Although they try to get maternal support, the remain tense at the end of the situation.

c. Avoidant Regulation

The mother cannot be referred to as a competent person to master the event or cannot be seen as a source of security. They express a negative emotional reaction. They try to regulate negative emotions by themselves, without being successful; that is, they remain tense at the end of the situation.

\section{RESULT AND DISCUSSION}

\subsection{Primary Emotions}

The result show that both categories children (toddler and preschooler) are express the positive affect such as joy and interest in a positive emotion regulation pattern. Most of them (toddler $=62.50 \%$; preschooler $=36.36 \%$ ) are using positive facial expression such as smiling and laughing. For preschooler they are more verbally expressive than toddler is and they know how to maintain the positive affect.

Smiling is critical as a means of developing a new social skill and is a key social signal (Campos, 2009; Santrock, 2011). In the second year, smiling continues to occur in such positive circumstances with parents, and smiling occurs when interacting with peers. Toddlers become increasingly aware of the social meaning of smiles especially toward positive affect.

The negative affect such as anger, surprise, and sadness dominated by negative emotion regulation pattern, as can be seen in the Figure 1 below:

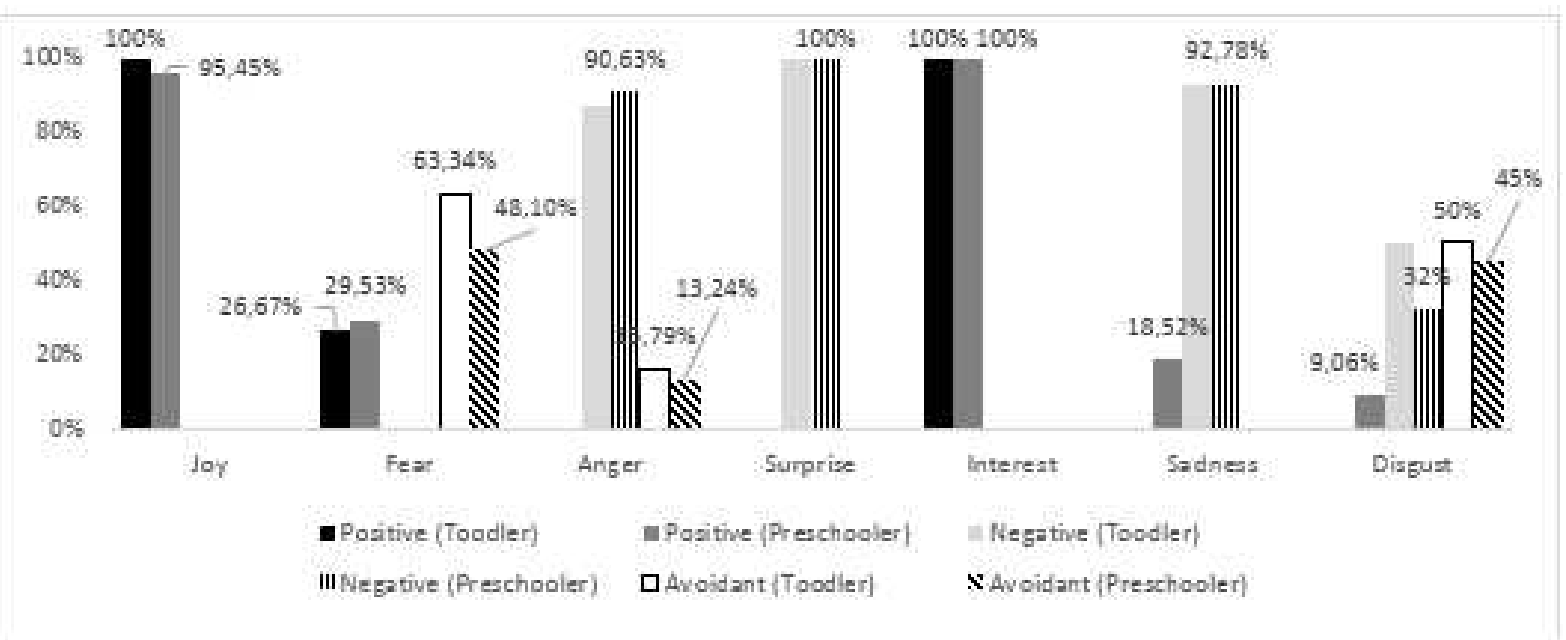

Figure 1. Emotion Regulation Pattern on Primary Emotion

Children may not have developed strategies to regulate negative emotional experiences by themselves. Most of them crying (69.23\%), tantrum, or shown aggressive behavior toward others $(56 \%)$, when they got angry or sad. The negative affect such as fear and disgust also dominated by negative emotional pattern. However, for these two emotions, children usually avoiding the stimulus, as can be 
seen in the Figure 1. These results are consistent with longitudinal research conducted by MalatestaMagai on 72 infants; it is known that usually children, especially toddler avoid the object or avoiding eye contact with the subject that makes them feel negative emotions (Malatesta-Magai, 1991).

The ways children express negative affect still less effective because they tend to use negative emotion regulation pattern and the results of this method was still causing tense in children. Toddlers lack of awareness about emotion can cause the lack of adequate behavior strategies promotes uncertainty and distress (Friedlmeier \& Trommsdorff, 1999). This is why toddler often seeking for support (usually the mother) to make them calmer in term to manage the negative affect.
Therefore, the mutual receptivity that caregivers and infants experience in each other's presence during the earliest stage of development is transformed developmentally. Sensitive, responsive parents help their infants grow emotionally, whether the infants respond in distressed or happy ways.

During early childhood, young children increasingly understand that certain situations are likely to evoke particular emotions and the caregivers' actions influence the children's neurobiological regulation of emotions and it is a good strategy for a caregiver to soothe the children before the children gets into an intense, agitated, uncontrolled state (Saarni, 2011). The sample of expression for positive, negative, and avoidant regulation pattern are listed in Table 2.

Table 2. Regulation Pattern, Reaction, and Sample of Expression of Primary Emotion

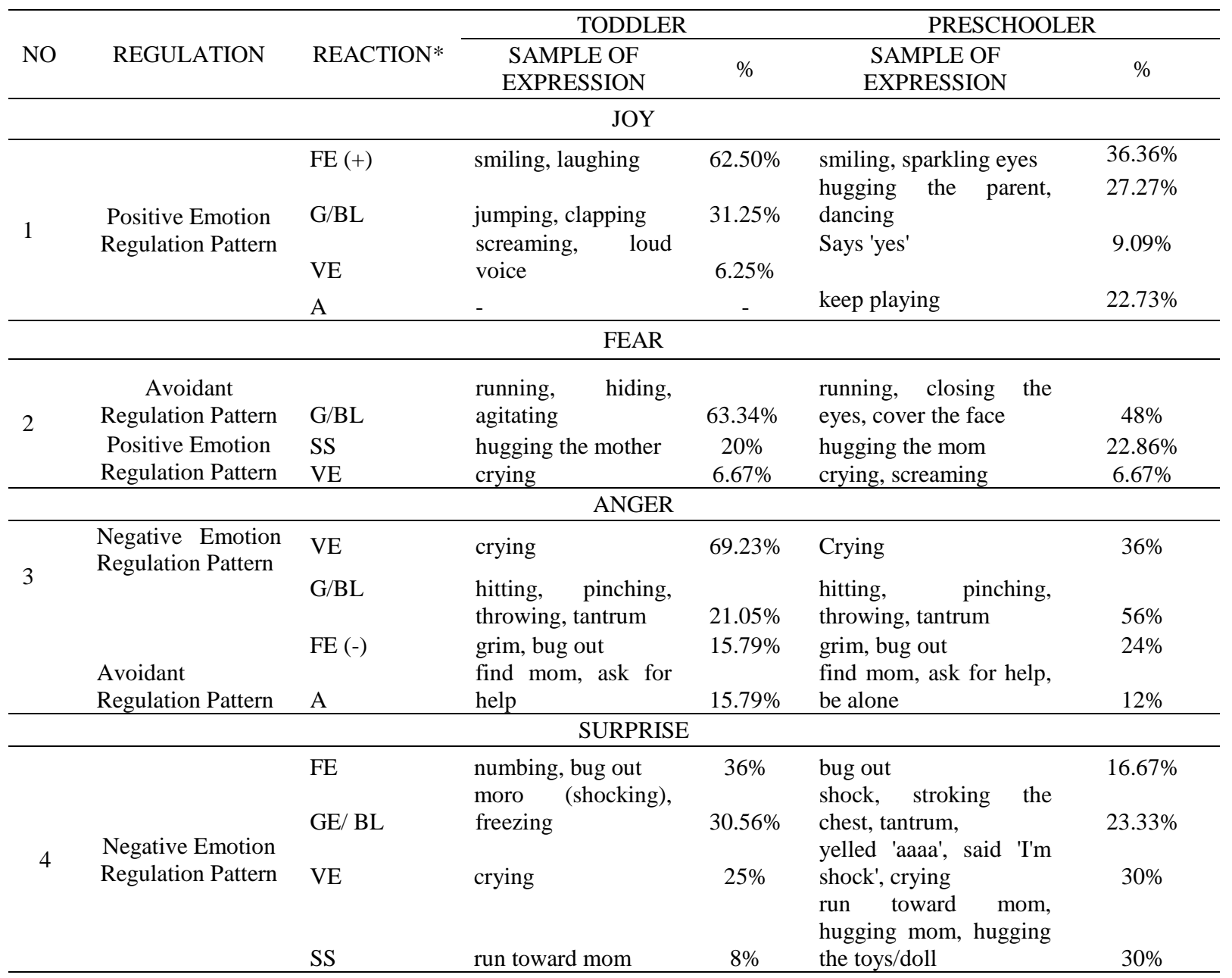


Table 2. Cont

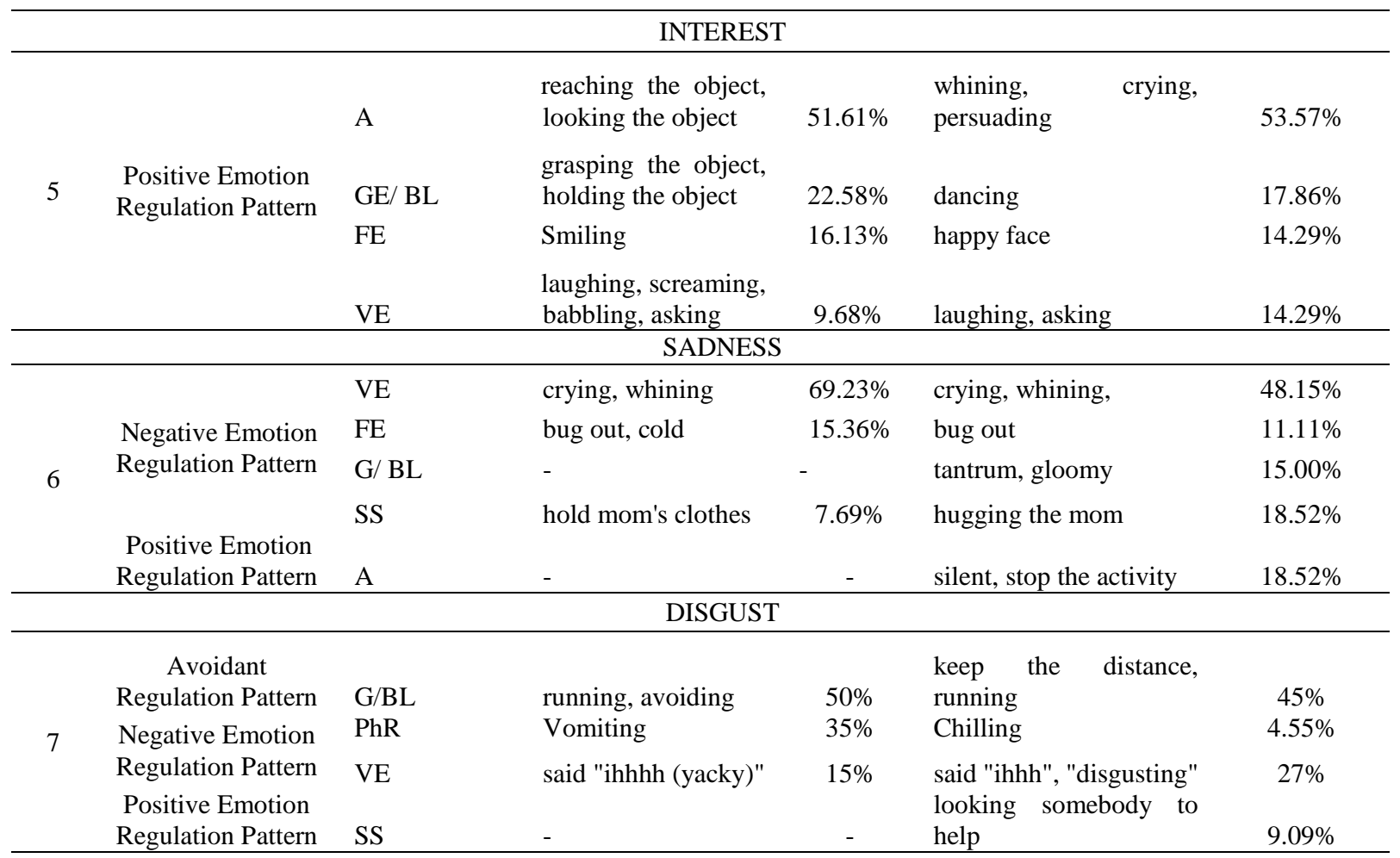

Note. FE (Facial Expression); G/BL (Gesture/Body Language); VE (Verbal Expression); A (Activity), PhR (Physical

Reaction); SS (Support Seeking)

\subsection{Self-Conscious Emotions}

To experience self-conscious emotions such as pride, shame, embarrassment, and guilt, children must be able to refer to themselves and be aware of themselves as distinct from others (Lewis, 2008). Self-conscious emotions do not appear to develop until self-awareness appears at around 18 months of age. During the early childhood years, emotions such as pride and guilt become more common. They are especially influenced by parents' responses to children's behavior.

In early childhood, children are constructing an understanding of the prototypical situational causes of basic emotions like distress, fear, and anger. They are also beginning to comprehend the internal origins of emotional experience. Consistent with this developing understanding, older preschooler children are also becoming aware of the privacy of emotional experience: that one's feelings do not have to be disclose to others and, in fact, other people can be fooled about what one is feeling (Thompson, Meyer, \& Jochem, 2009).
The result show that for negative selfconscious emotion such as jealousy, most of toddler $(50.37 \%)$ and preschooler $(61.29 \%)$ are express the emotion in a negative way, such as hitting, tantrum, or angry. Same as primary emotion, most of young children express their negative feeling in a negative emotion regulation pattern. Meanwhile for young children, especially preschooler, they should achieve several numbers of emotional competences (see table 3). As children acquire these emotional competence skills in a variety of contexts, they are more likely to effectively manage their emotions, become resilient in the face of stressful circumstances, and develop more positive relationships. Children exhibiting poorer capacities for emotional self-control are at risk of developing later (Santrock, 2011).

For toddler, the awareness of emotional expression can play a major role in relationship is still develop. They should learn how to inhibit, or minimize, the intensity and duration of emotional reactions. Same as result in this this research most of toddler $(63,64 \%)$ express their guilty feeling by crying, while preschoolers $(31,25 \%)$ express it by 
admitting their mistakes and asking for an apology. For preschooler children, they are capable of enlisting several constructive strategies of emotion regulation and, on occasion, talking about them, such as leaving an emotionally arousing situation, removing or restricting one's perception of emotionally arousing events, seeking comfort from a caregiver, and other behavioral strategies (Thompson, Meyer, \& Jochem, 2009).

Table 3. Emotional Competence Skill

\begin{tabular}{|c|c|}
\hline nal Competences & Exi \\
\hline $\begin{array}{l}\text { Using the vocabulary of } \\
\text { emotion terms in socially } \\
\text { and culturally appropriate } \\
\text { ways }\end{array}$ & $\begin{array}{l}\text { Appropriately describing } \\
\text { a social situation in one } \\
\text { culture's when a person is } \\
\text { feeling distress }\end{array}$ \\
\hline $\begin{array}{l}\text { Adaptively coping with } \\
\text { negative emotions by } \\
\text { using self-regulatory } \\
\text { strategies that reduce the } \\
\text { intensity or duration of } \\
\text { such emotional states }\end{array}$ & $\begin{array}{l}\text { Reducing anger by } \\
\text { walking away from an } \\
\text { aversive situation and } \\
\text { engaging in an activity } \\
\text { that takes one's mind off } \\
\text { of the aversive situation }\end{array}$ \\
\hline $\begin{array}{l}\text { Awareness that the } \\
\text { expression of emotions } \\
\text { plays a major role in a } \\
\text { relationship }\end{array}$ & $\begin{array}{l}\text { Knowing that expressing } \\
\text { anger toward a friend on a } \\
\text { regular basis is likely to } \\
\text { harm the friendship }\end{array}$ \\
\hline
\end{tabular}

Notes. Adapted from "Child Development 13th Edition," by John W. Santrock, 2011, p. 292

Actually, preschooler become more skilled using verbal expression to express their affect. Between 2 and 4 years of age, children considerably increase the number of terms they use to describe emotions. During this time, they are also learning about the causes and consequences of feelings. In the second and third year, the growth of children's communication skills and their understanding of others lead to many new powers of control over their own affective states. (Dunn \& Brown, 1991).

Parents can play an important role in helping young children regulate their emotions. Depending on how they talk with their children about emotion. Emotion-coaching parents monitor their children's emotions, view their children's negative emotions as opportunities for teaching, assist them in labeling emotions, and coach them in how to deal effectively with emotions. Moreover, the children of emotioncoaching parents are better at soothing themselves when they get upset, more effective in regulating their negative affect, focus their attention better, and have fewer behavior problems than children have emotion-dismissing parents (Santrock, 2011).

For shyness, most of toddler express it by avoiding eye contact $(53,33 \%)$, and the older children were trying to hide when they got shy (21, $74 \%)$. The emergence of self-referential emotions introduces greater complexity into the young child's emotional experience, and creates new challenges for emotion self-regulation as young children become increasingly concerned with how they appear in the eyes of others. Consequently, efforts to manage feelings now become enlisted to manage emotional expressions. Indeed, young children's efforts to avoid situations that evoke guilt or shame is an important emotional resource to early socialization. In particular, as children further mature, emotion-regulatory efforts become increasingly devoted to maintaining self-image and self-esteem in complex social situations involving peers, and children develop self-regulatory styles that fit well with emergent personality and selfawareness (Thompson, Meyer, \& Jochem, 2009).

For empathy, all the children capable of using positive emotion regulation pattern to express their feeling. Most of toddler can express the empathy by helping other $(60 \%)$ or just stay still when other children cry. Between the first and second birthdays, when witnessing another's distress children typically pause and may spend several seconds looking intently at the victim or even babbling with an inquiring tone. This is a strategy for regulating her own emotions by breaking her attention away from victim.

For preschooler, they can develop other strategies to express their empathy, such as express their feeling by using their vocabulary or they can show their feeling by appropriate facial expression, as shown in Table 4. Between the second and third year of life there is a gradual increase in the frequency of children's pro-social attempts to assist the person in distress (Robinson, 2009). Pro-social behaviors of preschooler children in this research include offering a help, comfort others, and by the age 3 years, children can express verbal sympathy (such as 'are you okay' or 'poor guy '). 
Table 4. Regulation Pattern, Reaction, and Sample of Expression of Self-Conscious Emotion

\begin{tabular}{|c|c|c|c|c|c|c|}
\hline \multirow[b]{2}{*}{ NO } & \multirow[b]{2}{*}{ REGULATION } & \multirow[b]{2}{*}{ REACTION* } & \multicolumn{2}{|l|}{ TODDLER } & \multicolumn{2}{|c|}{ PRESCHOOLER } \\
\hline & & & $\begin{array}{l}\text { SAMPLE OF } \\
\text { EXPRESSION }\end{array}$ & $\%$ & $\begin{array}{l}\text { SAMPLE OF } \\
\text { EXPRESSION }\end{array}$ & $\%$ \\
\hline \multicolumn{7}{|c|}{ JEALOUSY } \\
\hline \multirow[t]{4}{*}{1} & Negative Emotion & $\mathrm{G}$ & hitting, tantrum, & $50.37 \%$ & angry, hitting & $61.29 \%$ \\
\hline & Regulation Pattern & SS & $\begin{array}{l}\text { asking for cuddling, hold } \\
\text { mom's hand }\end{array}$ & $31.25 \%$ & hugging mom, & $29.03 \%$ \\
\hline & & VE & $\begin{array}{l}\text { crying, whining, sais } \\
\text { "watch out" }\end{array}$ & $25.00 \%$ & crying, yelling, & $3.23 \%$ \\
\hline & & FE & - & $0 \%$ & frowning, & $16.13 \%$ \\
\hline \multicolumn{7}{|c|}{ EMPATHY } \\
\hline \multirow[t]{3}{*}{2} & $\begin{array}{l}\text { Positive Emotion } \\
\text { Regulation Pattern }\end{array}$ & $\mathrm{A}$ & altruism, helping others & $60.00 \%$ & $\begin{array}{l}\text { defend, helping, giving } \\
\text { money }\end{array}$ & $67.00 \%$ \\
\hline & & $\mathrm{FE}$ & $\begin{array}{l}\text { sad expression, stay still } \\
\text { and watching }\end{array}$ & $40.00 \%$ & sad expression, & $28.57 \%$ \\
\hline & & VE & - & & said "poor guy" & $4.00 \%$ \\
\hline \multicolumn{7}{|c|}{ SHY } \\
\hline \multirow[t]{4}{*}{3} & $\begin{array}{l}\text { Negative Emotion } \\
\text { Regulation Pattern }\end{array}$ & $\mathrm{A}$ & $\begin{array}{l}\text { Avoiding eye contact, } \\
\text { cover the face, bowed, } \\
\text { avoiding the person }\end{array}$ & $53.33 \%$ & bowed & $26.09 \%$ \\
\hline & & $\mathrm{G}$ & freezing, hiding, running & 0.2667 & $\begin{array}{l}\text { freezing, hiding in his } \\
\text { room, running }\end{array}$ & $13.04 \%$ \\
\hline & $\begin{array}{l}\text { Avoidant Regulation } \\
\text { Pattern }\end{array}$ & SS & $\begin{array}{l}\text { hugging mom, hiding } \\
\text { behind mom }\end{array}$ & $20 \%$ & $\begin{array}{l}\text { running toward mom, } \\
\text { hugging mom, hiding } \\
\text { behind mom }\end{array}$ & $21.74 \%$ \\
\hline & \multicolumn{6}{|c|}{ GUILT } \\
\hline \multirow[t]{4}{*}{4} & $\begin{array}{l}\text { Positive Emotion } \\
\text { Regulation Pattern }\end{array}$ & $\mathrm{VE}$ & $\begin{array}{l}\text { crying, silent, said } \\
\text { "sorry", }\end{array}$ & $81.82 \%$ & crying, said "Sorry" & $56.25 \%$ \\
\hline & & A & - & 0 & $\begin{array}{l}\text { fixing toy, clean the } \\
\text { messy }\end{array}$ & $12.25 \%$ \\
\hline & $\begin{array}{l}\text { Negative Emotion } \\
\text { Regulation Pattern }\end{array}$ & $\mathrm{G} / \mathrm{BL}$ & stay still & $18.18 \%$ & hiding, avoiding & $12.50 \%$ \\
\hline & $\begin{array}{l}\text { Avoidant Regulation } \\
\text { Pattern }\end{array}$ & SS & - & 0 & hugging mom & $12.50 \%$ \\
\hline \multicolumn{7}{|c|}{ PRIDE } \\
\hline \multirow[t]{2}{*}{5} & $\begin{array}{l}\text { Positive Emotion } \\
\text { Regulation Pattern }\end{array}$ & VE & mumbling & $50.00 \%$ & mumbling, chatting & $61.11 \%$ \\
\hline & $\begin{array}{l}\text { Avoidant Regulation } \\
\text { Pattern }\end{array}$ & $\mathrm{G} / \mathrm{BL}$ & hiding, avoiding & $50.00 \%$ & hiding, avoiding & $5.56 \%$ \\
\hline
\end{tabular}

Notes. FE (Facial Expression); G/BL (Gesture/Body Language); VE (Verbal Expression); a (Activity); SS (Support Seeking)

\section{CONCLUSIONS}

One of the most important core features of emotional development is the ability to manage strong emotions and their expression in a constructive manner. Most of children are express the positive affect in a positive emotion regulation pattern. Children learning about the causes and consequences of feelings. They can use their communication skills and their understanding of others to control over their own affective states. Meanwhile, the negative affect is dominating by negative emotion regulation pattern. The ways children express negative affect still less effective and still causing tense in children.

The development of emotional regulation pattern is linear with cognitive, language, and selfawareness development in children. Toddler still learn how to inhibit, or minimize, the intensity and duration of emotional reactions. The experience of distress may evoke the child's activity to seek 
support to decrease or control the negative emotional state. Meanwhile, for preschooler children, they are capable of enlisting several constructive strategies of emotion regulation, such as talking about them, leaving an emotionally arousing situation, removing or restricting one's perception of emotionally arousing events, or seeking comfort.

Parents can play an important role in helping young children regulate their emotions. Parents can monitor their children's emotions, view their children's negative emotions as opportunities for teaching, assist them in labeling emotions, and coach them in how to deal effectively with emotions. For further research, it is necessary to consider the effect of parent-child interaction on young children's ability to regulate and express their emotions in a constructive manner.

\section{ACKNOWLEDGEMENTS}

We would like to express our appreciation to Faculty of Psychology Universitas Padjadjaran and to the Department of Human Development for all the support, and to the children and their mother for their participation in this research.

\section{REFERENCES}

Dunn, J., \& Brown, J. (1991). Relationships, Talk About Feelings, And The Development Of Affect Regulation In Early Childhood. In J. Garber, \& K. A. Dodge., The Development Of Emotion Regulation And Dysregulation (pp. 89-110). Cambridge: Cambridge University Press.

Friedlmeier, W., \& Trommsdorff, G. (1999). Emotion Regulation In Early Childhood : A CrossCultural Comparison Between German And Japanese Toddlers. Journal of Cross-Cultural Psychology Vol.30, 684-711.

Lewis, M. (2008). The Emergence of Human Emotions. In M. Lewi, J. M. Havland-Jones, \& L. F. Barret, Handbook of Emotion 3rd Edition (pp. 304319). New York: The Guilford Press.

Malatesta-Magai, C. (1991). Development Of Emotion Expression During Infancy: General Course And Patterns Of Individual Difference. In J. Garber, \& K. A. Dodge, The Development Of Emotion Regulation And Dysregulation (pp. 49-98). Cambridge: Cambridge University Press .

Robinson, J. (2009). Empathy and Prosocial Behavior. In J. B. benson, \& M. M. Haith, Socia and Emotional Development in Infancy and Early Childhood (pp. 129-138). Oxford: Elsevier Inc.
Saarni, C. (2011, September). Emotional Development in Childhood. Encyclopedia on Early Childhood Development .

Santrock, J. W. (2011). Child Development 13th Edition. New York: McGraw-Hill .

The National Scientific Council on the Developing . (2004). Children's Emotional Development Is Built into the Architecture. Massachusetts: Harvard University.

Thompson, R. A., Meyer, S., \& Jochem, a. R. (2009). Emotion Regulation. In J. B. Benson, \& M. M. Haith, Social And Emotional Development (pp. 119-128). Oxford: Elsevier.

Universitas Gadjah Mada, P. (2016, July 23). Perpustakaan Universitas Gadjah Mada. Retrieved from Universitas Gadjah Mada: http://lib.ugm.ac.id

Universitas Indonesia, L. (2016, July 23). Universitas Indonesia Library. Retrieved from Universitas Indonesia: http://www.lib.ui.ac.id

Universitas Padjadjaran, F. o. (2016, November 9). Perpustakaan Fakultas Psikologi Unpad. Retrieved from Perpustakaan Fakultas Psikologi Unpad: http://lib.psikologi.unpad.ac.id 